\title{
1,2,3- versus 1,2-Indeno Ring Fusions Influence Structure Property and Chirality of Corannulene Bowls
}

Shi Liu, ${ }^{\dagger}$ Loïc M. Roch, ${ }^{\dagger, \ddagger}$ Oliver Allemann, ${ }^{\dagger \dagger}$ Jun $\mathrm{Xu}^{\dagger}{ }^{\dagger}$ Nicolas Vanthuyne, ${ }^{\S}$ Kim K. Baldridge, ${ }^{*}{ }^{\dagger} \odot$ and Jay S. Siegel ${ }^{*} \dagger$

\author{
${ }^{\dagger}$ Health Science Platform, Tianjin University, 92 Weijin Road, Nankai District, Tianjin 300072, PR China \\ ${ }^{*}$ Department of Chemistry, University of Zurich, Winterthurerstrasse 190, 8057 Zurich, Switzerland \\ ${ }^{\S}$ Aix Marseille Univ, CNRS, Centrale Marseille, iSm2, Marseille, France
}

\begin{abstract}
Annulated corannulenes 3-5 form via distinct synthetic pathways: (i) Pd-catalyzed $\mathrm{sp}^{3} \mathrm{CH}$ insertion, (ii) $\mathrm{Pd}$ catalyzed aryl coupling, and (iii) silyl cation-promoted $\mathrm{C}-\mathrm{F}$ activation/ $\mathrm{CH}$ insertion. Crystal structure, redox, and photophysical studies elucidate the differing influence of 1,2,3versus 1,2-indeno ring fusions. Mono and dianions of 3-5 are characterized. Resolution of $\mathbf{4}$ gives enantiopure forms, allowing assessment of the bowl-inversion barrier.
\end{abstract}

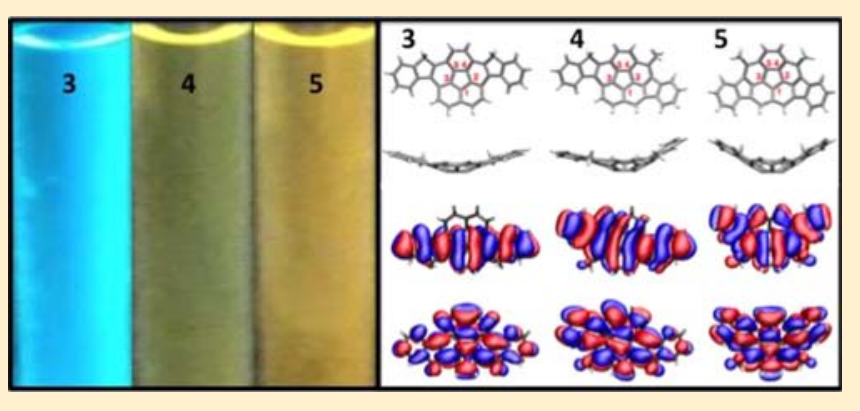

Scheme 1. Synthesis of $3-5^{a}$

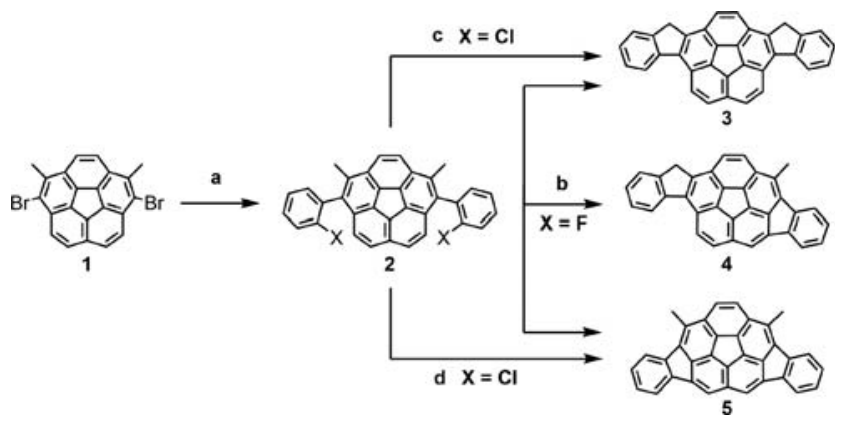

a (a) (2-Fluorophenyl)boronic acid, $\mathrm{K}_{2} \mathrm{CO}_{3}, \mathrm{Pd}\left(\mathrm{PPh}_{3}\right)_{4}, \mathrm{THF}, \mathrm{H}_{2} \mathrm{O}, 70$ ${ }^{\circ} \mathrm{C}, 15 \mathrm{~h}, 80 \%$; (b) $\left[{ }^{\mathrm{i}} \mathrm{Pr}_{3} \mathrm{Si}\right]\left[\mathrm{CHB}_{11} \mathrm{H}_{5} \mathrm{Br}_{6}\right]$, DMDMS, PhCl, MW, 120 ${ }^{\circ} \mathrm{C}, 200 \mathrm{~W}, 30 \mathrm{~h}$. Separated yield, 22 and $10 \%$ for 3 and 4, respectively. (c) $\mathrm{Pd}(\mathrm{OAc})_{2}$, Ligand [1,3-bis(2,6-diisopropylphenyl)-imidazolium chloride], NMP, $\mathrm{K}_{2} \mathrm{CO}_{3}, 125{ }^{\circ} \mathrm{C}, 20 \mathrm{~min}, 32 \%$; (d) $\mathrm{Pd}\left(\mathrm{PCy}_{3}\right)_{2} \mathrm{Cl}_{2}$, DBU, DMA, MW, $160{ }^{\circ} \mathrm{C}, 150 \mathrm{~W}, 30 \mathrm{~min}, 31 \%$.

of 3-5 in a ratio of 6.2:4.5:1 by HPLC analysis of the crude reaction mixture; isolated yields are typically $22 \%$ (3) and $10 \%$ (4). From a statistical analysis, this shows a selectivity factor of 2.5:1 for $\mathrm{Csp}^{3}$ over $\mathrm{Csp}^{2} \mathrm{CH}$ insertion. As noted before, the insensitivity to $\mathrm{CH}$ bond strength suggests a high-energy reactive intermediate (e.g., phenyl cation) with an early transition state to $\mathrm{CH}$ insertion. ${ }^{7}$ Use of substrate $\mathbf{2} \mathbf{b}$ enables selective formation of 3 by Pd-mediated $\mathrm{CH}$ insertion ${ }^{6}$ or 5 by Pd C-C coupling, ${ }^{3,4}$ but not of 4; isolated yields are typically $32 \%$ (3) and $31 \%$ (5).

\section{RESULTS AND DISCUSSION}

Coupling 1,6-dibromo-2,5-dimethylcorannulene with 2-fluoro or 2-chloro phenyl boronic acid gives $\mathbf{2 a}(\mathrm{X}=\mathrm{F})$ and $\mathbf{2} \mathbf{b}(\mathrm{X}=\mathrm{Cl})$, respectively. ${ }^{9}$ Treatment of $2 \mathrm{a}$ with silyl cation leads to a mixture 
Crystals suitable for X-ray diffraction analysis were obtained and structures solved for 3, 4-rac, and 5 (Figures 2 and 3, Table 1,
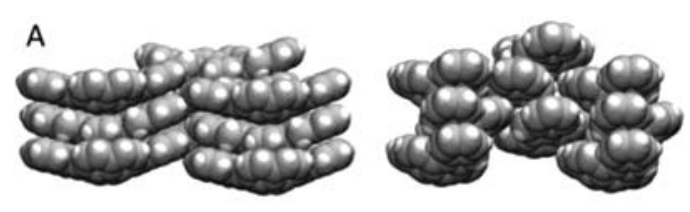

B
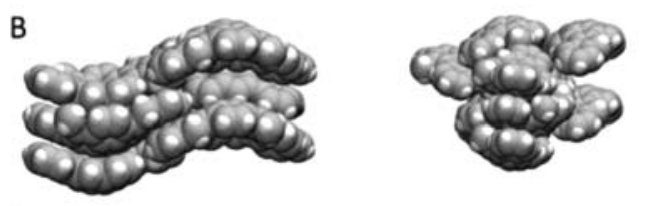

C
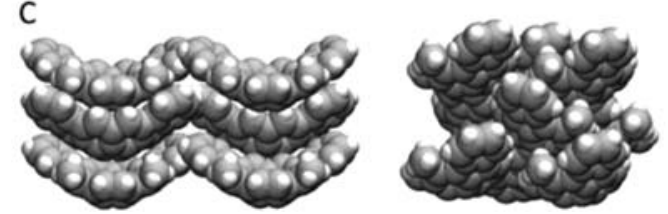

Figure 2. Crystal packing of (A) 3, (B) 4-rac, and (C) 5.

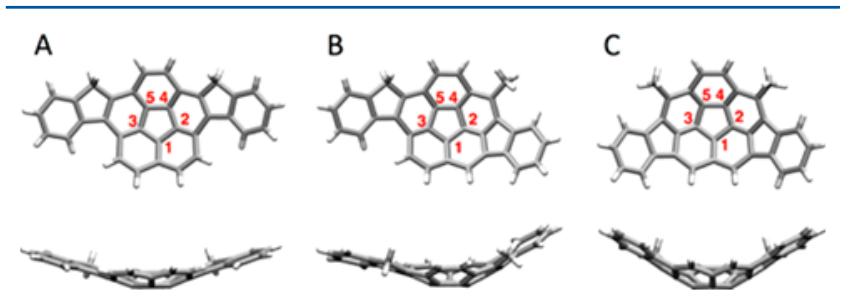

Figure 3. Representative X-ray structures (top and side view) of (A) 3, (B) 4 , and (C) 5 .

Table 1. Bowl Depths and Hub POAV Angles for 3-5

\begin{tabular}{|c|c|c|c|c|}
\hline \multirow[b]{2}{*}{ compd } & \multicolumn{2}{|c|}{ bowl depth $(\AA)$} & \multicolumn{2}{|c|}{ POAV (deg) } \\
\hline & X-ray ${ }^{a}$ & calcd $^{b}$ & $\mathrm{X}$-ray $^{a}$ & calcd $^{b}$ \\
\hline \multirow{3}{*}{3} & 0.829 & 0.864 & 7.8 & 8.0 \\
\hline & & & 7.6 & 8.1 \\
\hline & & & 8.0 & 8.1 \\
\hline \multirow{5}{*}{4} & 1.025 & 1.066 & 9.4 & 9.9 \\
\hline & & & 10.9 & 11.2 \\
\hline & & & 8.5 & 8.9 \\
\hline & & & 9.5 & 9.6 \\
\hline & & & 8.7 & 8.9 \\
\hline \multirow{3}{*}{5} & 1.177 & 1.217 & 10.5 & 11.2 \\
\hline & & & 11.3 & 11.6 \\
\hline & & & 10.0 & 10.0 \\
\hline
\end{tabular}

${ }^{a}$ Averaged values over all constitutionally equivalent positions. ${ }^{b}$ B97D/Def2-TZVPP optimized structures.

Supporting Information). The crystal packing diagrams reveal that all three compounds form rough columnar structures. In the case of $\mathbf{3}$ and $\mathbf{5}$, the unit cell is polar, and all columns point in the same direction. In the case of $\mathbf{4}$ as a racemate, the unit cell is nonpolar with columns of one enantiomer pointing up, and that of the other pointing down. In all cases, the columns are slip stacked, as seen previously with annulated various corannulene derivatives. $^{10,11,4}$ The degree of overlap between members along the stack is an important factor in determining the solid-state conductivity and photoelectronic properties. ${ }^{12,13}$

Bowl curvature, as gauged by the degree of pyramidalization of the hub carbon atoms, is scaled to the $\pi$-orbital axis vector
$($ POAV $)$ angles $\left(\right.$ e.g., corannulene $\left.=8.3^{\circ}\right) .^{2,14-17}$ Bowl depth is measured as the average of the distances of the hub atoms from the plane containing the ten rim-analogous atoms (e.g., corannulene $=0.875 \AA$ ). ${ }^{10}$ Average hub carbon POAV and bowl depth increase along the series 3-5: 7.8, 9.4, and $10.6^{\circ}$ and $0.829,1.025$, and $1.177 \AA$, respectively (cf. Table 1). Comparing the bowl depths and POAV angles of 3-5 with those of corannulene shows that vicinal-1,2 fusion flattens the bowl, whereas peri-2,3 fusion deepens the bowl. Consistent with previous observations, ${ }^{2,18}$ B97-D/Def2-TZVPP structures for 3-5 agree well with experiment.

Bowl-depth comparison across 3-5 reveals 4 to be roughly halfway between 3 and 5, but slightly closer to $\mathbf{5}$. Comparison of hub-atom curvature also places 4 roughly halfway between 3 and $\mathbf{5}$, although the individual values for $\mathbf{4}$ span a broad range. How then do the structural changes correlate with the properties manifest in these compounds?

Considering reduction potentials (Table 2), 3 with two fluorenoid subgraphs displays a first reduction potential of 2.25

Table 2. Cyclic Voltammetry Data of 3-5 in THF Solvent ${ }^{a}$

$\begin{array}{ccccc}\text { compd } & E_{\mathrm{c}}^{*}(\mathrm{~V}) & E_{1 / 2}(\mathrm{~V}) & E_{\mathrm{a}}-E_{\mathrm{c}}(\mathrm{V}) & I_{\mathrm{pa}} / I_{\mathrm{pc}}(\mathrm{V}) \\ \mathbf{3} & -2.25[-2.31]^{b} & -2.203 & 0.095 & -0.546 \\ \mathbf{4} & -2.01[-2.03] & -1.963 & 0.104 & -0.622 \\ \mathbf{5} & -1.91[-1.89] & -1.851 & 0.110 & -0.705\end{array}$

${ }^{a} \mathrm{CV}: 0.5 \mathrm{mM}$ in $0.1 \mathrm{M}$ TBAPF6/THF solution at $298 \mathrm{~K}$. Glassy carbon working electrodes; reference electrode $\mathrm{Ag} / \mathrm{Ag}+$ in $\mathrm{ACN}$; platinum wire counter electrode. Scan rate $=0.1 \mathrm{~V} / \mathrm{s}$. Internal standard ferrocenium/ferrocene couple, standard potential (+0.085 in THF). ${ }^{b} \mathrm{~B} 97-3^{27}$ (THF)/Def2-TZVPD//B97-D(GP)/Def2-TZVPP; calculated values in square brackets.

$\mathrm{eV}$, close to that of corannulene at $2.31 \mathrm{eV},{ }^{19}$ whereas 5 with two fluoranthenoid subgraphs shows a much lower reduction potential of $1.91 \mathrm{eV} .^{11}$ Here, the hybrid compound, 4, shows a reduction potential near the middle if somewhat closer to that of 5, similar to the characterization by bowl-depth. B97-3 (THF)/ Def2-TZVPD//B97-D(GP)/Def2-TZVPP calculated reduction potential values parallel the experiment findings. ${ }^{20}$ The B97-3 hybrid functional, which includes nonlocal exchange, has been previously established as an effective method for prediction of reduction potentials. ${ }^{2,11}$

In the case of photophysical properties, such as UV-vis absorption, and fluorescence properties (Table 3), 3 absorbs at

Table 3. Photophysical Parameters for $3-8^{a}$

\begin{tabular}{|c|c|c|c|c|c|c|}
\hline \# & $S^{b}$ & $\lambda_{\mathrm{ab}}$ & $\lambda_{\mathrm{em}}$ & $\tau_{\mathrm{f}}^{c}$ & $X^{2}$ & $\Phi_{\mathrm{f}}$ \\
\hline \multirow{3}{*}{3} & THF & 430 & 450,470 & 8.81 & 0.95 & 0.32 \\
\hline & $\mathrm{MCH}^{d}$ & 430 & 460,485 & & & \\
\hline & $\mathrm{IPA}^{e}$ & 430 & 575,620 & 602 & & \\
\hline \multirow{2}{*}{4} & THF & 350 & 560 & 3.97 & 0.81 & 0.02 \\
\hline & $\mathrm{MCH}^{d}$ & 350 & $520,555,595$ & & & \\
\hline \multirow{2}{*}{5} & THF & 350 & 575 & 6.36 & 1.16 & 0.02 \\
\hline & $\mathrm{MCH}^{d}$ & 350 & $525,565,615$ & & & \\
\hline 6 & THF & 500,600 & 700 & 2.10 & 1.26 & 0.03 \\
\hline 7 & THF & 450,600 & 700 & & & $<1 \%$ \\
\hline 8 & THF & 590,680 & 700 & & & $<1 \%$ \\
\hline
\end{tabular}

${ }^{a}$ Fluorescence lifetimes and quantum yields were measured using solutions with O.D. between 0.1 and 0.4 at $350 \mathrm{~nm}$ for three compounds. ${ }^{b} \mathrm{~S}=$ solvent $\mathrm{MCH}$ methylcyclohexane. ${ }^{c}$ Lifetime in $\mathrm{ns}$ (bold ms). ${ }^{d}$ At $99 \mathrm{~K} .{ }^{e}$ Phosphorescence. 
$\lambda_{\max }=430 \mathrm{~nm}$ in THF with $\lambda_{\mathrm{em}}=450 \mathrm{~nm}$ and a quantum yield of 0.32 , higher than that of corannulene. In contrast, $\mathbf{5}$ absorbs at $\lambda_{\max }=360 \mathrm{~nm}$ and emits at $\lambda_{\mathrm{em}}=575 \mathrm{~nm}(\Phi=0.02) .{ }^{11}$ The hybrid compound, 4 , shows a remarkable similarity to $5,\left(\lambda_{\max }=\right.$ $\left.360 \mathrm{~nm}, \lambda_{\mathrm{em}}=570 \mathrm{~nm}(\Phi=0.02)\right)$, distinctly not the midpoint of 3/5. Calculated HOMO/LUMO plots show remarkably similar patterns across 3-5 (Figure 4). As such, 3 could be considered as the "bigger box" consistent with a longer wavelength absorption.

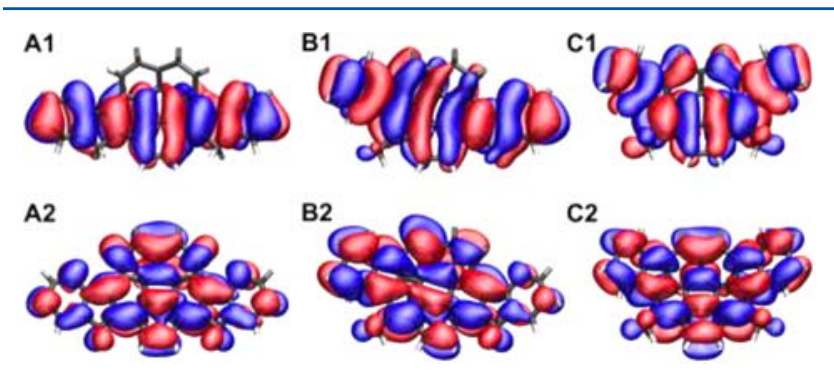

Figure 4. B97-D/Def2-TZVPP optimized structure HOMO (1) and LUMO (2) depictions for 3 (A), 4 (B), and 5 (C). Contour cutoff value is $0.01 \mathrm{e}^{-} / \AA^{3}$.

Deeper bowls (e.g., 5, $1.177 \AA$ ) have more overlap of $\sigma$ and $\pi$ orbitals, which leads to more intersystem crossing and diminished fluorescence quantum yield $\left(\Phi_{\mathrm{f}}=0.02\right)$. In contrast, shallower bowls (e.g., 3, $0.829 \AA$ A ) display stronger fluorescence $\left(\Phi_{\mathrm{f}}=0.32\right)$. From the absorption and emission spectra of 4 , it appears that local pyramidality dominates, and $\mathbf{4}$ behaves in a manner more similar to that of 5 than to that of 3. These observations are corroborated by TD-CAMB3LYP/Def2-TZVP(THF)//B97-D/Def2-TZVPP(GP) calculated results (see the Supporting Information). ${ }^{21}$ The use of TD-CAM-B3LYP for accurate prediction of spectra has been demonstrated in several benchmark studies. ${ }^{11,22}$

Bowl depth and curvature correlate with the bowl inversion barrier. $^{2,23,24}$ On this basis, the barriers are predicted as follows: for 3, lower than $40 \mathrm{~kJ} / \mathrm{mol}$; for 4, close to $100 \mathrm{~kJ} / \mathrm{mol}$; and for 5 , over $160 \mathrm{~kJ} / \mathrm{mol}$. As 4 is chiral, the predicted barrier implies that, if separated, the enantiomers would be configurationally stable for hours at room temperature in solution.

Racemic 4-rac was separated by preparative HPLC over chiral stationary phase to obtain $4 \mathbf{a}$ (first eluted, $\alpha_{\mathrm{D}}^{25}+1004\left(\mathrm{CHCl}_{3}, c=\right.$ $0.025))$ and $4 \mathbf{b}$ (second eluted, $\left.\alpha_{\mathrm{D}}^{25}-1009\left(\mathrm{CHCl}_{3}, c=0.024\right)\right)$. From enantiomerization kinetics, the bowl-inversion barrier was inferred to be $109.8 \mathrm{~kJ} / \mathrm{mol}\left(\mathrm{CHCl}_{3}, 62^{\circ} \mathrm{C}\right) .{ }^{25,26} \mathrm{Thus}$, a level of configurational stability for 4 is established at about $2 \mathrm{~h}$ at $60^{\circ} \mathrm{C}$ (over a day at ambient temperature). With configurationally stable enantiomers of $\mathbf{4}$ in hand, how can we best determine and assign the absolute configuration?

$\mathrm{X}$-ray diffractometry springs to mind as an answer to the above question; however, due to a lack of strong $\mathrm{X}$-ray scattering atoms, results can be ambiguous and alternative methods are desirable. One such method is the comparison of experimental and theoretical VCD spectra, which enables assignment of the configuration for $\mathbf{4 a}$ as being that shown with the bowl opening forward (Figure 5, details in the Supporting Information). ${ }^{27,28}$ The experimental spectrum comes from the subtraction of the spectrum of $\mathbf{4 b}$ from that of $\mathbf{4 a}$ to reduce baseline noise. The theoretically determined spectrum consists of a sum of Lorentzian distributions centered on the computed VCD frequencies, with a fixed width and the height proportional to the computed rotational constant. Note, experimental and

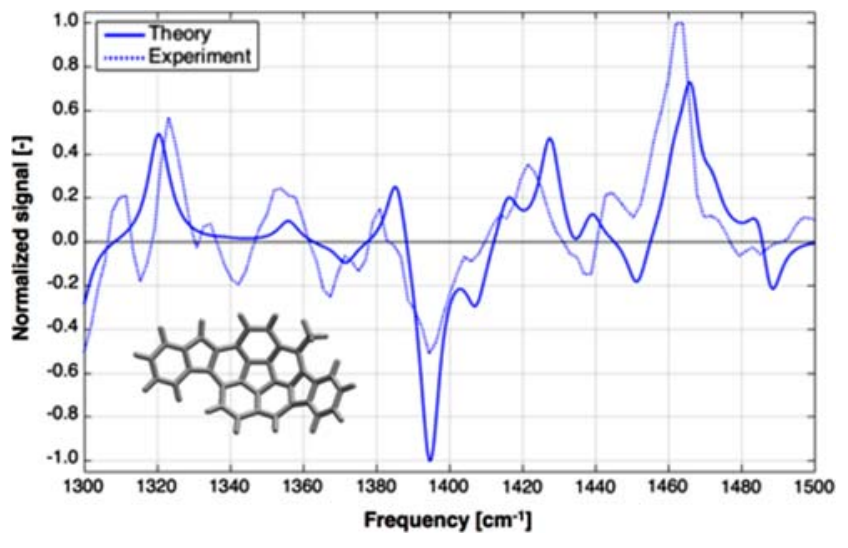

Figure 5. Experimental (dashed line) vs B97-D/Def2-TZVPP$\left(\mathrm{CHBr}_{3}\right) / /$ B97-D/Def2-TZVPP (solid line) VCD spectra first eluted fraction of 4. The simulated VCD spectrum consists of a sum of Lorentzian distributions, and the detailed theoretical approach is provided in the Supporting Information.

theoretical signals are normalized to the most intense peak in the displayed frequency range, and here the theoretical spectrum is shifted by ca. $12.5 \mathrm{~cm}^{-1}$ to compare better the transitional phases.

In addition to VCD, the ECD spectra of these two enantiomers were measured in $\mathrm{CHCl}_{3}$, (see the Supporting Information). ${ }^{29}$ Comparison of the measured and simulated ECD spectra of $4 \mathbf{a}$ further corroborates the assignment of configuration (Figure 6).

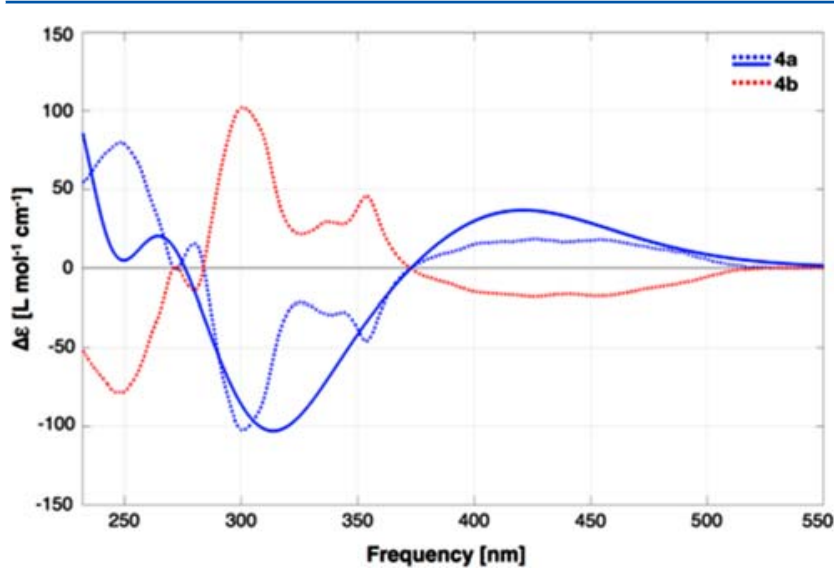

Figure 6. TD-CAMB3LYP/Def2-TZVP//B97-D/Def2-TZVPP (solid line) and ECD (dotted lines) spectra of $4 \mathbf{a}$ (blue) and $\mathbf{4 b}$ (red) at concentration of $0.0586 \mathrm{mmol} / \mathrm{L}$ in $\mathrm{CHCl}_{3}$. The simulated ECD spectrum consists of a sum of Gaussian distributions, and the detailed theoretical approach is provided in the Supporting Information.

Naming the configuration of the structure is less straightforward than knowing the structure's proper Cartesian reference. CIP methods do not readily apply to this kind of enantiomers. Ad hoc rules by Scott for C36 compounds, ${ }^{30}$ or by Sakurai for Sumanene ${ }^{31-33}$ (based on fullerenes), ${ }^{34,35}$ require additional elaboration.

The problem is compounded by the fact that a unique stereoelement is not easily defined. Simple 1,2-indenocorannulene is chiral but fluxional at room temperature; the 5-methyl substituted 1,2,3-indenocorannulene is chiral and most likely configurationally stable at STP. Does that imply two stereoelements and four isomers for 4 , which bears both subgraphs? Were it to be so simple, then two descriptors would solve the problem; 
however, the permutations that generate enantiomers of 1,2indenocorannulene or 5-methyl-1,2,3-indeno-corannulene in isolation do not yield diastereoisomers in combination but rather constitutional isomers. Thus, the set of four isomers from two "elements" would not describe a diastereoisomeric mixture (Figure 7). Therefore, naming the enantiomers of 1,2-

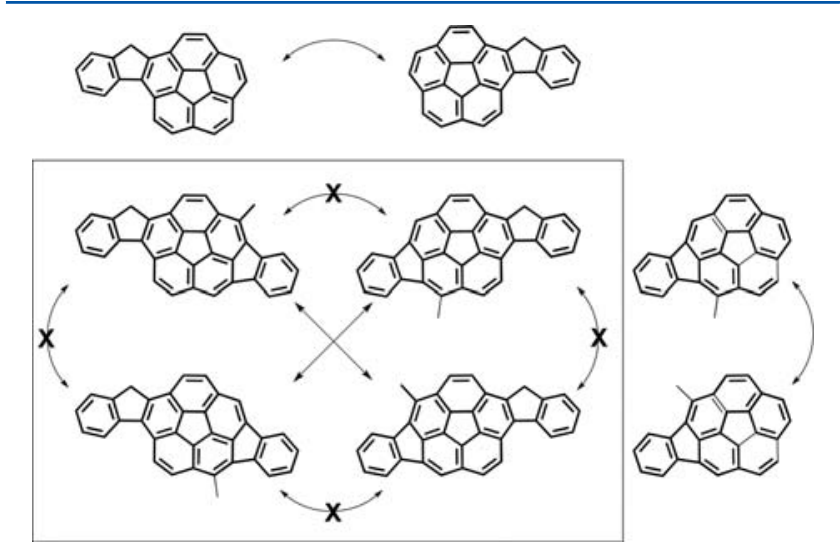

Figure 7. Isomer elements in 4: Outside the box, horizontal and vertical pairs are enantiomeric stereoisomers. Inside the box, horizontal and vertical pairs are not stereoisomers; only cross diagonal relations are enantiomeric stereoisomers. Stereodescriptors for the external relations cannot serve the internal relations, restricted to stereoisomerism.

indenocorannulene or 5-methyl-1,2,3-indeno-corannulene independently as $\mathrm{M} / \mathrm{P}(\mathrm{C} / \mathrm{A})$ may seem satisfying but would misrepresent isomers of 4 to be $\mathrm{M}, \mathrm{M} / \mathrm{M}, \mathrm{P} / \mathrm{P}, \mathrm{M} / \mathrm{P}, \mathrm{P}(\mathrm{C}, \mathrm{C} / \mathrm{C}$, A/A, C/A, A) stereoisomers, which they are not. The Scott and Sakurai stereodescriptors thus are not general/elementary but $a d$ hoc.

In the absence of an authoritative rule of nomenclature, one can create a name based on property, as was done a century ago before CIP. Historically, polarimetry values taken at the sodium D line were used to name compounds as $(d / l$ or \pm$)$, but in this instance, solubility and optical rotary power at the sodium $\mathrm{D}$ line make this difficult. The Cotton effect at $370 \mathrm{~nm}$ works to assign the first eluted enantiomer $4 \mathbf{a}$ as the $\operatorname{Cot}_{375}(+)$-enantiomer (cf. Figure 6), but unfortunately, the name does not assist one to readily visualize the model. More work is needed here.

Structurally, one sees two fluorenoid subgraphs within the skeleton of 3. The $\mathrm{Csp}^{3}-\mathrm{H}$ protons of fluorene have a reference $\mathrm{pK}_{\mathrm{a}}$ value of around 22.6 in $\mathrm{DMSO}^{36}$ (similar to the alpha proton in acetone). Therefore, it seems reasonable to generate the dianion of 3 by deprotonation with LDA (Scheme 2). ${ }^{37,38}$ Surprisingly, although single deprotonation of $\mathbf{4}$ was expected, double deprotonation was observed. On the basis of this result, double-deprotonation of $\mathbf{5}$ was attempted. ${ }^{1} \mathrm{H}$ NMR clearly showed a chemical shift pattern and integration consistent with the loss of two protons. Quenching with deuterated water exchanged $\mathrm{D}$ for $\mathrm{H}$ at the acidic $\mathrm{Csp}^{3}-\mathrm{H}$ site.

The dianions of 3-5 are long-lived in the absence of water and oxygen. THF solutions of the dianions were prepared in the glovebox and sealed before removal. This sealed sample was used for spectroscopic studies. In addition to clean ${ }^{1} \mathrm{H}$ NMR spectra, these dianions display broad absorption spectra out to $800 \mathrm{~nm}$, and their fluorescence emission is shifted to the NIR region but with less significant quantum yields with respect to their precursors (c.f. Table 3; Figure 8) The broad absorption and long wavelength emission indicate a free electron flow in these anions.

Scheme 2. Deprotonation of 3-5 in THF
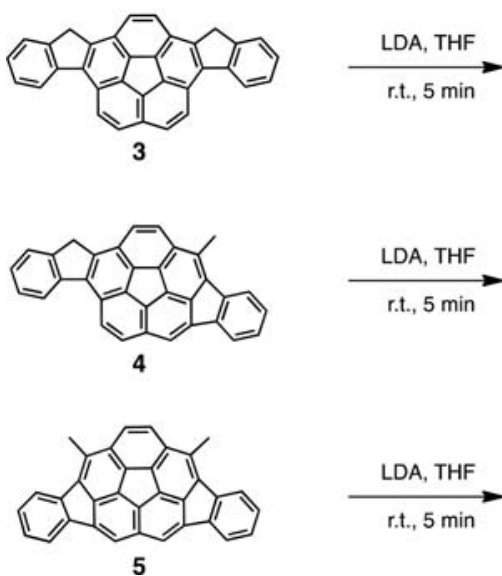

5 min
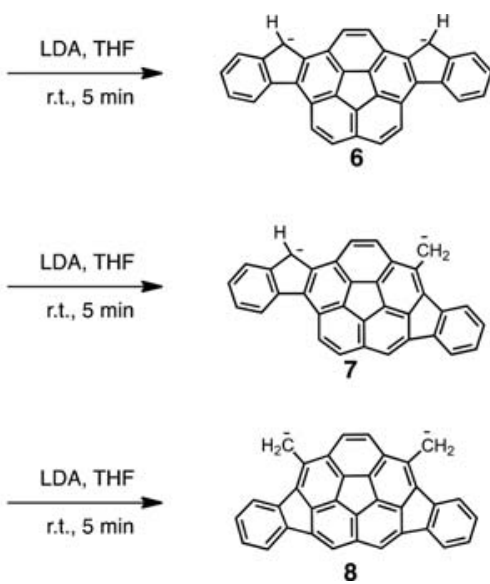

8

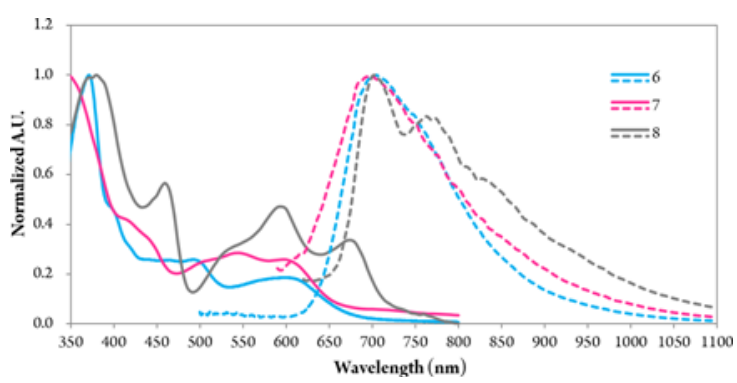

Figure 8. UV-vis absorption and fluorescence emission of compound 6-8 in $0.05 \mathrm{M}$ LDA in THF.

$\omega$ B97X-D/Def2-TZVPP(THF)//B97-D/Def2-TZVPP calculated $\mathrm{p} K_{\mathrm{a}}$ results predict a difference of $1.64 \mathrm{p} K_{\mathrm{a}}$ units between 3 and indene, while that between 5 and toluene is $7.62 p K$ units (see Figure 9, and the Supporting Information for detailed

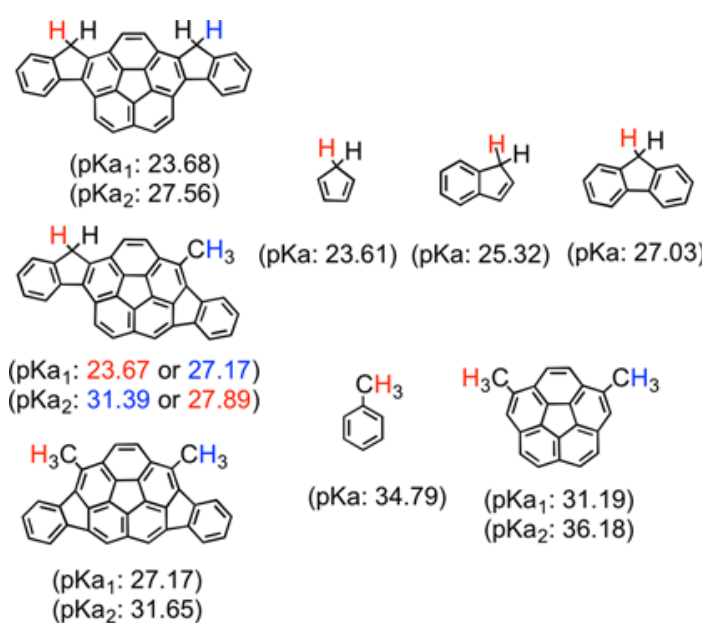

Figure 9. B97X-D/Def2-TZVPP(THF)//B97-D/Def2-TZVPP determined $\mathrm{p} K_{\mathrm{a}}$ values for 3-5 (top panel, from left to right).

information on the procedure). Given the large difference in reduction potential favoring the radical anion of 5 over 4 over 3 , one hypothesis could be that more favorable reduction potential correlates with stronger electron withdrawing ability. Indeed, predictions of the $\mathrm{p} K_{\mathrm{a}}$ for methyl protons in dimethylcorannulene, and $\mathbf{5}$ suggest that $\mathbf{5}$ is easier to reduce and easier to deprotonate (Figure 9). Previous methodology calibrations have 
established high correlation of calculated $\mathrm{p} K_{\mathrm{a}}$ with experiment using this method (also see the Supporting Information). ${ }^{18}$

In contrast, the $\mathrm{p} K_{\mathrm{a} 1}$ of $\mathbf{4}$ shows similarities with both $\mathbf{3}$ and $\mathbf{5}$. Computations predict the $\mathrm{p} K_{\mathrm{a} 1}$ value of the indene-like proton (in red) in 4 to be essentially identical to that in 3 (i.e., 23.68 vs $23.67,3$ vs 4 ), and the $\mathrm{p} K_{\mathrm{a} 1}$ value of the methylcorannulene-like proton (in blue) in $\mathbf{4}$ is essentially identical to that in $\mathbf{5}$ (both 27.17). ${ }^{39}$ The contrast between electrochemical potentials and $\mathrm{p} K_{\mathrm{a} 1}$ values among 3-5 warranted further study.

Independent treatment of 3-5 with excess potassium $t$ butoxide in THF produced the dianion, monoanion, and neutral compounds, respectively. These results fit with the prediction that the fluorene-like methylene protons are substantially more acidic than the methyl protons. Treatment of 3 with lithium $t$ butoxide provided additional insight into the story, because there was no evidence of deprotonation. Counter ion dependent acidbase reactivity is not uncommon but often associated with strong steric factors. ${ }^{40}$ In the present case, the situation could be similar to the counterion dependent reduction of corannulene with lithium versus cesium. ${ }^{41}$

A head-to-head titration of $\mathbf{3}$ and $\mathbf{4}$ with potassium t-butoxide in THF allowed the determination of the differential $\mathrm{p} K_{\mathrm{a} 1}$ value to be within a tenth of a $\mathrm{pK}$ unit. The experiment showed that proton exchange was slow on the NMR time scale so that integration of the neutral and deprotonated species could be used to assess the relative deprotonation of each component.

In summary, three annulated corannulene derivatives were synthesized via three different methods, and the absolute configuration of the chiral molecule determined by VCD. In particular, the enantiomers of chiral corannulene $\mathbf{4}$ were isolated, the bowl-to-bowl inversion barrier determined, and the absolute configuration assigned by comparison of experimental and calculated vibrational circular dichroism spectra. The associated photophysical and electrochemical properties were compared using experimental as well as theoretical methodologies.

\section{EXPERIMENTAL SECTION}

General Information. Most commercially available reagents were used without purification (Ferrocene was purified by sublimation). Reactions were carried out in glass equipment and monitored for completion by analyzing a small sample (after suitable workup) by TLC, sometimes by ${ }^{1} \mathrm{H}$ NMR analysis. Column chromatography was performed using silica gel (100-200 mesh). Solvents for reactions were distilled prior to their use. Solvents for sensitive reactions were taken from a solvent purification system (Innovative Technology) or dried by passing through activated $\mathrm{Al}_{2} \mathrm{O}_{3}$, then degassed by freezepump-thaw method and stored over molecular sieves. Evaporation of the solvents in vacuo was done with a rotary evaporator at $40{ }^{\circ} \mathrm{C}$. Pure products were dried under high vacuum. Thin layer chromatography (TLC) was performed with Energy Chemical TLC plates (silica gel on aluminum support) with the indicated mobile phase; the spots were visualized by UV light ( 254 and $365 \mathrm{~nm}$ ). Microwave reactions were performed in a CEM Discover Microwave Reactor with integrated active cooling. They were performed in a microwave tube sealed with a PTFE cap under pressure (set maximum pressure 250 PSI). Reaction temperatures were measured by an external temperature sensor. UVvis measurements were carried out on HITACHI U-3900. Infrared spectra (IR) were recorded on a JASCO FT/IR-4100 Fourier Transform Infrared Spectrometer. IR frequencies are given in $\mathrm{cm}^{-1}$. Signal intensities are presented as weak $(\mathrm{w})$, medium $(\mathrm{m})$ and strong (s). ${ }^{1} \mathrm{H},{ }^{13} \mathrm{C}$, and ${ }^{19} \mathrm{~F}$ NMR spectra were recorded using either 600 or 400 MHz BRUKER AVANCE spectrometer at $298 \mathrm{~K}$. ${ }^{1} \mathrm{H}$ NMR spectra were recorded as follows: in $\mathrm{CDCl}_{3} / \mathrm{CD}_{2} \mathrm{Cl}_{2} / \mathrm{TCE}-d_{2} / \mathrm{THF}-d_{8}$, using Bruker AVANCE III (600 or $400 \mathrm{MHz}) ; \delta$ in ppm relative to $\mathrm{CDCl}_{3}(\delta 7.26)$, $\mathrm{CD}_{2} \mathrm{Cl}_{2}(\delta 5.32)$, TCE- $d_{2}(\delta 6.00)$, and THF- $d_{8}(\delta 3.58,1.72) ; J$ in Hz. ${ }^{19} \mathrm{~F}$ NMR spectra were recorded as follows: $\mathrm{CDCl}_{3}$; Bruker AVANCE III
(564 MHz); $\delta$ in ppm relative to $\mathrm{C}_{6} \mathrm{~F}_{6}(\delta-162.2 \mathrm{ppm}) .{ }^{13} \mathrm{C}$ NMR spectra were recorded as follows: in $\mathrm{CDCl}_{3} / \mathrm{CD}_{2} \mathrm{Cl}_{2} / \mathrm{TCE}-d_{2} / \mathrm{THF}-d_{8}$; Bruker AVANCE III (150 or $100 \mathrm{MHz}) ; \delta$ in ppm relative to $\mathrm{CDCl}_{3}(\delta$ 77.16), $\mathrm{CD}_{2} \mathrm{Cl}_{2}\left(\delta\right.$ 53.84), TCE- $d_{2}\left(\delta\right.$ 73.78), and THF- $d_{8}(\delta$ 67.21, $25.31)$. Chemical shifts of all NMR spectra were reported in ppm with the solvent resonance as the internal standard (except ${ }^{19} \mathrm{~F}$ NMR). Highresolution mass spectra (HR-MS) recorded for accurate mass analysis, were performed on a Q-TOF micro (Bruker Compass Data Analysis 4.0) spectrometer. Single plate-shaped crystals of the compound 3-5 were obtained by recrystallization from toluene. The crystal structures were obtained from Rigaku XtalAB PRO MM007 DW.

1,6-Bis(2-fluorophenyl)-2,5-dimethylcorannulene 2a. 1,6-Dibromo-2,5-dimethylcorannulene 1 (801.3 mg, $1.837 \mathrm{mmol}$ ), (2fluorophenyl)boronic acid (912.9 mg, $6.543 \mathrm{mmol}), \mathrm{Pd}\left(\mathrm{PPh}_{3}\right)_{4}$ $(127.6 \mathrm{mg}, 0.1104 \mathrm{mmol})$, and $\mathrm{K}_{2} \mathrm{CO}_{3}(1.561 \mathrm{~g}, 11.29 \mathrm{mmol})$ were added subsequently to a 2-necked round bottom flask equipped with a condenser, which was then purged with 3 cycles of vacuum $/ \mathrm{N}_{2}$. Degassed THF $(70 \mathrm{~mL})$ and $\mathrm{H}_{2} \mathrm{O}(8 \mathrm{~mL})$ were added and then the mango yellow mixture was heated to $70{ }^{\circ} \mathrm{C}$. After almost complete consumption of 1 , the dark reaction mixture was quenched with sat. aq. $\mathrm{NaHCO}_{3}(50 \mathrm{~mL})$, then the aqueous phase extracted with $\mathrm{DCM}(3 \times 50$ $\mathrm{mL})$. The combined organic phases were washed with brine $(50 \mathrm{~mL})$, then dried over $\mathrm{MgSO}_{4}$, filtered, and concentrated in vacuo to afford the crude product as a dark brown solid. It was purified afterward by flash column chromatography (hexane) to afford the pure product as a slightly yellow solid $(691.4 \mathrm{mg}, 1.482 \mathrm{mmol})$ in $80 \%$ yield. IR ( $\mathrm{KBr})$ 3052w, 2922w, 1493m, 1449m, 823m, 793m, 756s, 649w. ${ }^{1} \mathrm{H}$ NMR $\left(600 \mathrm{MHz}, \mathrm{CD}_{2} \mathrm{Cl}_{2}\right): 8.07(\mathrm{~s}, 2 \mathrm{H}), 7.69(\mathrm{~d}, J=8.8,2 \mathrm{H}), 7.56-7.21(\mathrm{~m}$, $10 \mathrm{H}), 2.65(\mathrm{~s}, 6 \mathrm{H}) .{ }^{19} \mathrm{~F}-\mathrm{NMR}\left(564 \mathrm{MHz}, \mathrm{CD}_{2} \mathrm{Cl}_{2}\right):-113.86,-114.00$. HR-MS (ESI-qTOF) $m / z:[\mathrm{M}+\mathrm{Na}]^{+}$Calcd for $\mathrm{C}_{34} \mathrm{H}_{20} \mathrm{~F}_{2} \mathrm{Na} 489.1425$. Found 489.1415 .

2.2.1,6-Bis(2-chlorofluorophenyl)-2,5dimethylcorannulene 2b. 1,6-Dibromo-2,5-dimethylcorannulene $1(183.4 \mathrm{mg}, 0.4205 \mathrm{mmol})$, (2-Chlorophenyl)boronic acid (232.4 mg, $1.486 \mathrm{mmol}), \mathrm{Pd}\left(\mathrm{PPh}_{3}\right)_{4}$ (33.5 mg, $0.0282 \mathrm{mmol}$ ), and $\mathrm{K}_{2} \mathrm{CO}_{3}(349.6 \mathrm{mg}, 2.529 \mathrm{mmol})$ were added subsequently to a 2-necked bottom flask equipped with a condenser, which was then purged with 3 cycles of vacuum $/ \mathrm{N}_{2}$. Degassed THF $(15.8 \mathrm{~mL})$ and $\mathrm{H}_{2} \mathrm{O}(1.8 \mathrm{~mL})$ were added, and then the mango yellow mixture was heated to $70{ }^{\circ} \mathrm{C}$. After the almost consumption of 1 , the dark reaction mixture was quenched with saturated $\mathrm{NaHCO}_{3}(20 \mathrm{~mL})$ and then the aqueous phase was extracted with DCM $(3 \times 30 \mathrm{~mL})$. The combined organic phase was washed with brine $(25 \mathrm{~mL})$, then dried over $\mathrm{MgSO}_{4}$, filtered, concentrated in vacuo to afford the crude product as a dark brown solid. It was purified afterward by flash column (hexane/DCM 10:1) to afford the pure product as a slightly yellow solid $(0.1542 \mathrm{~g}, 0.31 \mathrm{mmol})$ in $73 \%$ yield. $\mathrm{IR}(\mathrm{KBr}) 3051 \mathrm{w}, 2919 \mathrm{w}, 1434 \mathrm{~m}, 1059 \mathrm{~m}, 845 \mathrm{~m}, 799 \mathrm{~s}, 751 \mathrm{~s}, 734 \mathrm{~m}$, $707 \mathrm{~m} .{ }^{1} \mathrm{H}$ NMR $\left(600 \mathrm{MHz}, \mathrm{CDCl}_{3}\right): 8.02(\mathrm{~d}, J=3.9,2 \mathrm{H}), 7.66-7.56$ $(\mathrm{m}, 4 \mathrm{H}), 7.49-7.30(\mathrm{~m}, 5 \mathrm{H}), 7.25-7.10(\mathrm{~m}, 3 \mathrm{H}), 2.58(\mathrm{~s}, 6 \mathrm{H}) .{ }^{13} \mathrm{C}$ NMR $\left(150 \mathrm{MHz}, \mathrm{CDCl}_{3}\right): 137.9,137.8,135.8,135.72,135.70,135.6$, $134.87,134.85,134.81,134.7,134.54,134.52,134.13,134.10,132.4$, $132.3,131.0,130.78,130.73,129.99,129.93,129.88,129.75,129.2$, $127.29,127.26,126.8,126.7,125.91,125.86,125.49,125.47,15.94$, 15.91. HR-MS (ESI-qTOF) $m / z:[\mathrm{M}+\mathrm{Na}]^{+}$Calcd for $\mathrm{C}_{34} \mathrm{H}_{20} \mathrm{Cl}_{2} \mathrm{Na}$ 521.0833. Found 521.0834.

Compound 3. C-F Activation. 1,6-Bis(2-fluorophenyl)-2,5-dimethylcorannulene $(2 \mathrm{a}, 90.0 \mathrm{mg}, 0.193 \mathrm{mmol}),\left[{ }^{\mathrm{i}} \mathrm{Pr}_{3} \mathrm{Si}\right]\left[\mathrm{CHB}_{11} \mathrm{H}_{5} \mathrm{Br}_{6}\right]$ (18.5 mg, $0.024 \mathrm{mmol}$ ), and DMDMS (dimethyldimesitylsilane) (92 $\mathrm{mg}, 0.310 \mathrm{mmol}$ ) were added to a microwave tube inside the glovebox. The compounds were dissolved in $\mathrm{PhCl}(12 \mathrm{~mL})$. The reaction mixture was heated at $200 \mathrm{~W}$ with cooling turned on for $10 \mathrm{~h}$ with temperature below $125{ }^{\circ} \mathrm{C}$. The reaction was monitored by ${ }^{1} \mathrm{H}$ NMR and additional DMDMS $(90.5 \mathrm{mg}, 0.305 \mathrm{mmol})$ and $\left[{ }^{\mathrm{i}} \mathrm{Pr}_{3} \mathrm{Si}\right]\left[\mathrm{CHB}_{11} \mathrm{H}_{5} \mathrm{Br}_{6}\right](18.1 \mathrm{mg}$, $0.023 \mathrm{mmol}$ ) were added. After cooling to room temperature, the mixture was diluted with EtOAc, and one drop of $\mathrm{H}_{2} \mathrm{O}$ was added to quench the reaction. Solvent was evaporated to afford the crude product as dark green solid. It was purified afterward by flash column to afford the pure product as a yellow solid $(18.1 \mathrm{mg}, 0.042 \mathrm{mmol})$ in $22 \%$ yield.

C-Cl Activation. 1,6-Bis(2-chlorofluorophenyl)-2,5-dimethylcorannulene (2b, $40.3 \mathrm{mg}, 0.081 \mathrm{mmol}), \mathrm{Pd}(\mathrm{OAc})_{2}(7.2 \mathrm{mg}, 0.032 \mathrm{mmol}), \mathrm{L}$ 
(4.9 mg, $0.013 \mathrm{mmol}$ ), and $\mathrm{K}_{2} \mathrm{CO}_{3}(48.8 \mathrm{mg}, 0.353 \mathrm{mmol})$ were added subsequently to $2 \mathrm{~mL}$ of anhydrous and degassed NMP in a sealed tube inside glovebox. The sealed tube was taken out to an oil bath and heated to $125-130{ }^{\circ} \mathrm{C}$ for $20 \mathrm{~min}$, and then TLC control showed full consumption of starting material. The resulting dark green reaction mixture was diluted in $30 \mathrm{~mL}$ of toluene, and then washed with brine for 4 times. The organic phase was dried over $\mathrm{MgSO}_{4}$ and concentrated in vacuo by rotary evaporator to afford black solid. The crude was subjected to flash column and eluted with hexane/DCM (20:3) to afford pure product as yellow solid $(10.9 \mathrm{mg}, 0.026 \mathrm{mmol})$ in $32 \%$ yield. IR $(\mathrm{KBr})$ 3040w, 2919w, 1464m, 1391w, 793m, 762m, 722s, 669w. UV-vis $\lambda_{\max }$ (THF) nm: 430, 305, 280. ${ }^{1} \mathrm{H}$ NMR $\left(400 \mathrm{MHz}, \mathrm{CDCl}_{3}\right): 8.48(\mathrm{~d}, J=$ $8.8,2 \mathrm{H}), 8.42(\mathrm{~d}, J=7.7,2 \mathrm{H}), 8.02(\mathrm{~s}, 2 \mathrm{H}), 7.96(\mathrm{~d}, J=8.8,2 \mathrm{H}), 7.69(\mathrm{~d}$, $J=7.4,2 \mathrm{H}), 7.53(\mathrm{t}, J=7.4,2 \mathrm{H}), 7.37(\mathrm{t}, J=7.4,2 \mathrm{H}), 4.31(\mathrm{~s}, 4 \mathrm{H}) .{ }^{1} \mathrm{H}$ NMR $\left(400 \mathrm{MHz}\right.$, THF- $\left.d_{8}\right): 8.57(\mathrm{~d}, J=8.8,2 \mathrm{H}), 8.47(\mathrm{~d}, J=7.7,2 \mathrm{H})$, $8.09(\mathrm{~s}, 2 \mathrm{H}), 8.00(\mathrm{~d}, J=8.8,2 \mathrm{H}), 7.68(\mathrm{~d}, J=7.5,2 \mathrm{H}), 7.48(\mathrm{t}, J=7.5$, $2 \mathrm{H}), 7.33(\mathrm{t}, J=7.4,2 \mathrm{H}), 4.35(\mathrm{~s}, 4 \mathrm{H}) .{ }^{1} \mathrm{H}$ NMR $\left(600 \mathrm{MHz}\right.$, TCE- $\left.d_{2}\right)$ : $8.44(\mathrm{~d}, J=8.7,2 \mathrm{H}), 8.40(\mathrm{~d}, J=7.6,2 \mathrm{H}), 7.99(\mathrm{~s}, 2 \mathrm{H}), 7.95(\mathrm{~d}, J=8.7$, $2 \mathrm{H}), 7.71(\mathrm{~d}, J=7.3,2 \mathrm{H}), 7.55(\mathrm{t}, J=7.4,2 \mathrm{H}), 7.40(\mathrm{t}, J=7.3,2 \mathrm{H}), 4.29$ $(\mathrm{s}, 4 \mathrm{H}) .{ }^{13} \mathrm{C}$ NMR $\left(150 \mathrm{MHz}, \mathrm{TCE}-d_{2}\right): 143.7,142.4,142.2,138.7$, 135.4, 135.0, 134.4, 129.4, 127.7, 127.6, 127.1, 127.0, 126.1, 125.5, 125.0, 124.9, 122.0, 35.6. HR-MS (ESI-qTOF) $\mathrm{m} / z:[\mathrm{M}+\mathrm{Na}]^{+}$Calcd for $\mathrm{C}_{34} \mathrm{H}_{18} \mathrm{Na}$ 449.1301. Found 449.1282.

Compound 4. 1,6-Bis (2-fluorophenyl)-2,5-dimethyl-corannulene (2a, $90.0 \mathrm{mg}, 0.193 \mathrm{mmol}),\left[{ }^{\mathrm{i}} \mathrm{Pr}_{3} \mathrm{Si}\right]\left[\mathrm{CHB}_{11} \mathrm{H}_{5} \mathrm{Br}_{6}\right](18.5 \mathrm{mg}, 0.024$ $\mathrm{mmol}$ ), and DMDMS (92 $\mathrm{mg}, 0.310 \mathrm{mmol}$ ) were added to a microwave tube inside the glovebox. The compounds were dissolved in $\mathrm{PhCl}(12$ $\mathrm{mL}$ ). The reaction mixture was heated at $200 \mathrm{~W}$ with cooling turned on for $10 \mathrm{~h}$ with temperature below $125^{\circ} \mathrm{C}$. The reaction was monitored by ${ }^{1} \mathrm{H}$ NMR and additional DMDMS (90.5 mg, $0.305 \mathrm{mmol}$ ) and $\left[{ }^{\mathrm{i}} \mathrm{Pr}_{3} \mathrm{Si}\right]\left[\mathrm{CHB}_{11} \mathrm{H}_{5} \mathrm{Br}_{6}\right](18.1 \mathrm{mg}, 0.023 \mathrm{mmol})$ was added. After cooling to room temperature, the mixture was diluted with EtOAc, and one drop of $\mathrm{H}_{2} \mathrm{O}$ was added to quench the reaction. Solvent was evaporated to afford the crude product as dark green solid. It was purified afterward by flash column and then by prep TLC (cyclohexane/DCM 10:2) to afford the pure product as a yellow orange solid $(8.0 \mathrm{mg}, 0.019 \mathrm{mmol})$ in $10 \%$ yield. IR (KBr): 3044w, 2920w, 787s, 763w, 715m. UV-vis $\lambda$ max (THF) nm: 350, 330, 280. ${ }^{1} \mathrm{H}$ NMR (400 MHz, THF- $\left.d_{8}\right) 8.34$ (d, $J=$ $7.7,1 \mathrm{H}), 8.29(\mathrm{~d}, J=9.0,1 \mathrm{H}), 7.99(\mathrm{~d}, J=9.0,1 \mathrm{H}), 7.86-7.76(\mathrm{~m}, 4 \mathrm{H})$, $7.74(\mathrm{~d}, J=7.0,1 \mathrm{H}), 7.62(\mathrm{~d}, J=7.5,1 \mathrm{H}), 7.44(\mathrm{t}, J=7.5,1 \mathrm{H}), 7.29(\mathrm{t}, J=$ $7.4,1 \mathrm{H}), 7.26-7.16(\mathrm{~m}, 2 \mathrm{H}), 4.37-4.01(\mathrm{dd}, J=179.4,23.0,2 \mathrm{H}), 2.87$ $(\mathrm{s}, 3 \mathrm{H}) .{ }^{1} \mathrm{H}$ NMR $\left(600 \mathrm{MHz}, \mathrm{TCE}-d_{2}\right): 8.29(\mathrm{~d}, J=7.7,1 \mathrm{H}), 8.18(\mathrm{~d}, J=$ $8.9,1 \mathrm{H}), 7.89(\mathrm{~d}, J=9.0,1 \mathrm{H}), 7.77-7.72(\mathrm{~m}, 3 \mathrm{H}), 7.70(\mathrm{~d}, J=6.9,1 \mathrm{H})$, 7.69-7.64 (m, 2H), 7.51 (t, J= 7.45, 1H), $7.37(\mathrm{t}, J=7.1,1 \mathrm{H}), 7.30-$ $7.22(\mathrm{dtd}, J=19.9,7.4,1.3,2 \mathrm{H}), 4.17(\mathrm{dd}, J=144.1,22.6,2 \mathrm{H}), 2.85(\mathrm{~s}$, $3 \mathrm{H}) .{ }^{13} \mathrm{C}$ NMR (150 MHz, TCE- $\left.d_{2}\right): 143.59,143.53,142.02$, 141.96, $140.4,140.3,139.8,138.9,138.0,137.8,137.2,136.9,136.7,136.4,135.8$, $135.03,135.00,128.9,128.5,127.8,127.5,126.9,126.5,126.0,125.8$, 124.9, 124.6, 124.3, 124.1, 121.9(2C), 121.5, 35.5, 15.0. HR-MS (ESIqTOF) $m / z:[\mathrm{M}+\mathrm{Na}]^{+}$Calcd for $\mathrm{C}_{34} \mathrm{H}_{18} \mathrm{Na}$ 449.1301. Found 449.1289.

Compound 5. To an oven-dried $10 \mathrm{~mL}$ microwave tube equipped with a magnetic stirring bar were added 1,6-bis(2-chlorophenyl)-2,5dimethylcorannulene $(\mathbf{2 b}, 20.0 \mathrm{mg}, 0.040 \mathrm{mmol})$ and trans-dichlorobis(tricyclohexylphosphine)-palladium $(11.8 \mathrm{mg}, 0.016 \mathrm{mmol})$. The vial was sealed with a PTFE-silicon septum and purged with 3 cycles of vacuum $/ \mathrm{N}_{2}$. Anhydrous dimethylacetamide $(1 \mathrm{~mL})$ and 1,8 diazabicyclo[5.4.0] undec-7-ene $(0.2 \mathrm{~mL}, 0.669 \mathrm{mmol})$ were added to this solid mixture, and the vessel was irradiated in a CEM Discover Microwave Unit, at $155^{\circ} \mathrm{C}$ for $30 \mathrm{~min}$ with $150 \mathrm{~W}$ power max and high stirring using a standard method. Upon completion, the reaction mixture was diluted with DCM, extracted with $0.1 \mathrm{~N} \mathrm{HCl}, \mathrm{H}_{2} \mathrm{O}$ and washed with brine. The solution was dried over magnesium sulfate, filtered, and concentrated in vacuo to afford the crude product. It was purified by flash column (hexane/DCM 10:1) to afford the pure product as a yellow product $(5.3 \mathrm{mg}, 0.012 \mathrm{mmol})$ in $31 \%$ yield. IR ( $\mathrm{KBr})$ : $3048 \mathrm{w}, 2923 \mathrm{~s}, 2853 \mathrm{~m}, 897 \mathrm{w}, 785 \mathrm{~s}, 751 \mathrm{~s}, 732 \mathrm{w}, 709 \mathrm{w}, 671 \mathrm{w}$. UV-vis $\lambda \max (\mathrm{THF}) \mathrm{nm}: 350,330,280 .{ }^{1} \mathrm{H}$ NMR $\left(400 \mathrm{MHz}, \mathrm{CDCl}_{3}\right): 7.71(\mathrm{~s}$, $2 \mathrm{H}), 7.69(\mathrm{~m}, 2 \mathrm{H}), 7.64(\mathrm{~m}, 2 \mathrm{H}), 7.54(\mathrm{~s}, 2 \mathrm{H}), 7.23-7.19(\mathrm{~m}, 4 \mathrm{H}), 2.75$ $(\mathrm{s}, 6 \mathrm{H}) .{ }^{1} \mathrm{H}$ NMR $\left(600 \mathrm{MHz}, \mathrm{THF}-d_{8}\right): 7.80(\mathrm{~s}, 2 \mathrm{H}), 7.74(\mathrm{~d}, J=7.3 \mathrm{~Hz}$,
2H), 7.70-7.67 (m, 2H), 7.65 (s, 2H), 7.24-7.15 (m, 4H), $2.75(\mathrm{~s}, 6 \mathrm{H})$. ${ }^{1} \mathrm{H}$ NMR $\left(600 \mathrm{MHz}\right.$, TCE- $\left.d_{2}\right): 7.73(\mathrm{~s}, 2 \mathrm{H}), 7.71(\mathrm{~m}, 2 \mathrm{H}), 7.67(\mathrm{~m}, 2 \mathrm{H})$, 7.57(s, $2 \mathrm{H}), 7,25(\mathrm{~m}, 4 \mathrm{H}), 2.76(\mathrm{~s}, 6 \mathrm{H}) .{ }^{13} \mathrm{C}$ NMR $\left(150 \mathrm{MHz}, \mathrm{TCE}-d_{2}\right)$ : 142.3, 141.7, 141.0, 139.8, 139.7, 139.6, 138.4, 137.4, 136.9, 134.5, 134.2, 128.2, 127.7, 125.1, 124.1, 123.1, 121.6, 14.8. HR-MS (ESI-qTOF) $\mathrm{m} / \mathrm{z}$ : $[\mathrm{M}+\mathrm{Na}]^{+}$Calcd for $\mathrm{C}_{34} \mathrm{H}_{18} \mathrm{Na}$ 449.1301. Found 449.1289.

Preparation of LDA. An oven-dried 2-necked round-bottomed (5 $\mathrm{mL}$ ) flask was purged with 3 cycles of vacuum $/ \mathrm{N}_{2}$. Thereto were subsequently added anhydrous and degassed ${ }^{\mathrm{i}} \mathrm{Pr}_{2} \mathrm{NH}(0.12 \mathrm{~mL})$ and THF ( $1 \mathrm{~mL})$. The flask was cooled in a liquid $\mathrm{N}_{2}$ and EtOAc bath. Then, $n$-Buli $(2.5 \mathrm{M}, 0.28 \mathrm{~mL})$ was added dropwise to the mixture. After $0.5 \mathrm{~h}$, the cooled bath was removed, and the mixture was warmed up to room temperature and transferred to the glovebox.

Compound 6. Compound $3(2 \mathrm{mg}, 0.0047 \mathrm{mmol})$ was dissolved in $0.5 \mathrm{~mL}$ of anhydrous and degassed THF- $d_{8}$ inside glovebox. Thereto was added $30 \mathrm{uL}$ of freshly prepared LDA solution $(0.5 \mathrm{M})$ via a microsyringe. A dark green solution was obtained and transferred to a sealed NMR tube; then, NMR spectra were collected. UV-vis $\lambda_{\max }$ (THF) nm: 600, 500, 370. ${ }^{1} \mathrm{H}$ NMR $\left(600 \mathrm{MHz}\right.$, THF- $\left.d_{8}\right): 8.27-8.23$ $(\mathrm{m}, 2 \mathrm{H}), 7.99(\mathrm{~d}, J=8.4,2 \mathrm{H}), 7.90(\mathrm{~s}, 2 \mathrm{H}), 7.49-7.46(\mathrm{~m}, 2 \mathrm{H}), 7.43(\mathrm{~d}$, $J=8.4,2 \mathrm{H}), 6.87(\mathrm{~s}, 2 \mathrm{H}), 6.71-6.65(\mathrm{~m}, 4 \mathrm{H}) .{ }^{13} \mathrm{C}$ NMR $(150 \mathrm{MHz}$, THF- $\left.d_{8}\right): 138.1,135.3,135.2,133.6,133.3,127.8,127.4,127.2,125.6$, $122.7,121.0,120.8,119.8,118.7,115.4,112.9,112.7,90.6$.

Compound 7. Compound 4 ( $3.2 \mathrm{mg}, 0.0075 \mathrm{mmol})$ was dissolved in $0.5 \mathrm{~mL}$ of anhydrous and degassed THF- $d_{8}$ inside glovebox. Thereto was added $40 \mathrm{uL}$ of freshly prepared LDA solution $(0.5 \mathrm{M})$ via a microsyringe. A dark solution was obtained and transferred to a sealed NMR tube; then NMR spectra were collected. UV-vis $\lambda_{\max }$ (THF) nm: 600, 400. ${ }^{1} \mathrm{H}$ NMR $\left(400 \mathrm{MHz}, \mathrm{THF}-d_{8}\right): 8.13-8.07(\mathrm{~m}, 1 \mathrm{H}), 7.65(\mathrm{~d}, J$ $=7.4 \mathrm{~Hz}, 1 \mathrm{H}), 7.59(\mathrm{~d}, J=8.7 \mathrm{~Hz}, 1 \mathrm{H}), 7.51(\mathrm{~s}, 1 \mathrm{H}), 7.47(\mathrm{~d}, J=8.2 \mathrm{~Hz}$, $1 \mathrm{H}), 7.40-7.22(\mathrm{~m}, 4 \mathrm{H}), 6.93-6.84(\mathrm{~m}, 1 \mathrm{H}), 6.65(\mathrm{~s}, 1 \mathrm{H}), 6.63-6.54$ $(\mathrm{m}, 2 \mathrm{H}), 6.45(\mathrm{t}, J=7.2 \mathrm{~Hz}, 1 \mathrm{H}), 5.00(\mathrm{~d}, J=2.3 \mathrm{~Hz}, 1 \mathrm{H}), 4.51(\mathrm{~d}, J=2.4$ $\mathrm{Hz}, 1 \mathrm{H}) .{ }^{13} \mathrm{C}$ NMR $\left(150 \mathrm{MHz}\right.$, THF- $\left.d_{8}\right): 147.0,145.5,144.2,143.6$, 141.4, 135.2, 135.1, 134.9, 134.2, 132.3, 132.2, 131.9, 129.8, 128.9, 128.5, 127.0, 126.9, 125.5, 124.0, 123.9, 122.3, 121.3, 120.0, 119.7, 119.1, 118.7, $116.1,115.3,113.6,113.0,112.7,100.9,89.5,83.9$.

Compound 8. Compound 5 ( $3.5 \mathrm{mg}, 0.0082 \mathrm{mmol})$ was dissolved in $0.5 \mathrm{~mL}$ of anhydrous and degassed THF- $d_{8}$ inside glovebox. Thereto was added $40 \mathrm{uL}$ of freshly prepared LDA solution $(0.5 \mathrm{M})$ via a microsyringe. An olive green solution was obtained and transferred to a sealed NMR tube; then, NMR spectra were collected. UV-vis $\lambda_{\max }$ (THF) nm: 680, 590, 455. ${ }^{1} \mathrm{H}$ NMR $\left(600 \mathrm{MHz}, \mathrm{THF}-d_{8}\right): 7.52$ (dd, $J=$ $7.5,1.2 \mathrm{~Hz}, 2 \mathrm{H}), 7.48(\mathrm{~s}, 2 \mathrm{H}), 7.20(\mathrm{~d}, J=7.6 \mathrm{~Hz}, 2 \mathrm{H}), 6.93(\mathrm{~s}, 2 \mathrm{H}), 6.78$ $(\mathrm{td}, J=7.4,1.3 \mathrm{~Hz}, 2 \mathrm{H}), 6.38(\mathrm{td}, J=7.2,1.1 \mathrm{~Hz}, 2 \mathrm{H}), 4.86(\mathrm{~d}, J=2.4 \mathrm{~Hz}$, $2 \mathrm{H}), 4.36(\mathrm{~d}, J=2.4 \mathrm{~Hz}, 2 \mathrm{H}) .{ }^{13} \mathrm{C}$ NMR $\left(150 \mathrm{MHz}, \mathrm{THF}-d_{8}\right): 149.3$, 146.9, 144.6, 143.7, 142.0, 136.3, 132.4, 130.3, 129.9, 129.1, 124.9, 124.0, $123.1,118.6,115.7,112.9,101.6,83.7$.

Compounds 9-11 (Deuterated 3-5). To the freshly prepared compounds $6-8,5-10 \mathrm{uL}$ of $\mathrm{D}_{2} \mathrm{O}$ was added via a microsyringe. The color of the reaction mixture turned back to yellow after the addition. The solvent was removed by rotary evaporator, and ${ }^{1} \mathrm{H}$ NMR spectra were collected. ${ }^{1} \mathrm{H}$ NMR $\left(600 \mathrm{MHz}, \mathrm{CDCl}_{3}, 9\right): 8.46(\mathrm{~d}, J=8.8,2 \mathrm{H})$, $8.41(\mathrm{~d}, J=7.7,2 \mathrm{H}), 8.00(\mathrm{~s}, 2 \mathrm{H}), 7.95(\mathrm{~d}, J=8.8,2 \mathrm{H}), 7.69(\mathrm{~d}, J=7.4$, $2 \mathrm{H}), 7.53(\mathrm{t}, J=7.4,2 \mathrm{H}), 7.37(\mathrm{t}, J=7.4,2 \mathrm{H}), 4.30(\mathrm{~s}, 0.28 \mathrm{H}), 4.28(\mathrm{~s}$, $1.39 \mathrm{H}) .{ }^{1} \mathrm{H}$ NMR $\left(600 \mathrm{MHz}, \mathrm{TCE}-d_{2}, 10\right): 8.30(\mathrm{~d}, J=7.6 \mathrm{~Hz}, 1 \mathrm{H}), 8.20$ $(\mathrm{d}, J=8.8 \mathrm{~Hz}, 1 \mathrm{H}), 7.92(\mathrm{~d}, J=8.9 \mathrm{~Hz}, 1 \mathrm{H}), 7.79-7.75(\mathrm{~m}, 3 \mathrm{H}), 7.74-$ $7.68(\mathrm{~m}, 2 \mathrm{H}), 7.66(\mathrm{~d}, J=7.4 \mathrm{~Hz}, 1 \mathrm{H}), 7.53-7.48(\mathrm{~m}, 1 \mathrm{H}), 7.39-7.35$ $(\mathrm{m}, 1 \mathrm{H}), 7.26(\mathrm{dtd}, J=20.0,7.5,1.3 \mathrm{~Hz}, 2 \mathrm{H}), 2.88(\mathrm{~s}, 0.13 \mathrm{H}), 2.86(\mathrm{t}, J=$ 2.2, $1.51 \mathrm{H}) .{ }^{1} \mathrm{H}$ NMR $\left(600 \mathrm{MHz}, \mathrm{CDCl}_{3}, 11\right): 7.71(\mathrm{~s}, 2 \mathrm{H}), 7.70-7.67$ $(\mathrm{m}, 2 \mathrm{H}), 7.64(\mathrm{~m}, 2 \mathrm{H}), 7.54(\mathrm{~s}, 2 \mathrm{H}), 7.21(\mathrm{~m}, 4 \mathrm{H}), 2.75(\mathrm{~s}, 1.01 \mathrm{H})$, 2.74-2.72 (m, 3.10H).

Compound 12 (Monoanion of 3). Compound 3 ( $2.5 \mathrm{mg}$, 0.0058 $\mathrm{mmol}$ ) was suspended in $0.3 \mathrm{~mL}$ of anhydrous and degassed THF- $d_{8}$ inside glovebox. Thereto was added $t$-BuOK in THF- $d_{8}$ ( $345 \mathrm{uL}, 0.023$ $\mathrm{mmol}$ ). A reddish brown solution was obtained and transferred to a sealed NMR tube; then, NMR spectra were collected. ${ }^{1} \mathrm{H}$ NMR (600 MHz, THF- $\left.d_{8}\right): 8.46-8.31(\mathrm{~m}, 3 \mathrm{H}), 8.18(\mathrm{dd}, J=16.9,8.5 \mathrm{~Hz}, 2 \mathrm{H}), 7.90$ $(\mathrm{d}, J=8.4 \mathrm{~Hz}, 1 \mathrm{H}), 7.76(\mathrm{~d}, J=8.5 \mathrm{~Hz}, 1 \mathrm{H}), 7.72(\mathrm{~d}, J=8.6 \mathrm{~Hz}, 1 \mathrm{H})$, $7.70-7.57(\mathrm{~m}, 2 \mathrm{H}), 7.42(\mathrm{t}, J=7.5 \mathrm{~Hz}, 1 \mathrm{H}), 7.24(\mathrm{t}, J=7.3 \mathrm{~Hz}, 1 \mathrm{H}), 7.09$ $(\mathrm{s}, 1 \mathrm{H}), 6.92-6.87(\mathrm{~m}, J=6.0,3.0 \mathrm{~Hz}, 2 \mathrm{H}), 4.29(\mathrm{~s}, 2 \mathrm{H}) .{ }^{13} \mathrm{C}$ NMR $(150$ 
MHz, THF- $\left.d_{8}\right): 144.9,144.6,142.7,137.27,137.23,136.2,135.4,134.6$, 134.1, 133.9, 133.6, 130.0, 128.8, 127.8, 127.5, 127.4, 127.00, 126.97, $126.5,126.16,126.11,125.8,125.6,125.3,122.9,122.4,120.5$ (2C), $119.8,117.6,115.2,112.6,92.3,36.2$.

Compound 13 (Monoanion of 4). Compound 4 ( $3.5 \mathrm{mg}, 0.0082$ $\mathrm{mmol}$ ) was dissolved in $0.5 \mathrm{~mL}$ of anhydrous and degassed THF- $d_{8}$ inside glovebox. Thereto was added excess $t$ - $\mathrm{BuOK}(2 \mathrm{mg}, 0.018 \mathrm{mmol})$. A green solution was obtained and transferred to a sealed NMR tube; then, NMR spectra were collected. ${ }^{1} \mathrm{H}$ NMR $\left(600 \mathrm{MHz}, \mathrm{THF}-d_{8}\right): \delta$ $8.23-8.18(\mathrm{~m}, 1 \mathrm{H}), 8.07(\mathrm{~d}, J=8.8 \mathrm{~Hz}, 1 \mathrm{H}), 7.89(\mathrm{~d}, J=8.8 \mathrm{~Hz}, 1 \mathrm{H})$, $7.83(\mathrm{~d}, J=8.8 \mathrm{~Hz}, 1 \mathrm{H}), 7.79-7.74(\mathrm{~m}, 1 \mathrm{H}), 7.67-7.63(\mathrm{~m}, 1 \mathrm{H}), 7.59$ $(\mathrm{s}, 1 \mathrm{H}), 7.51(\mathrm{~m}, 2 \mathrm{H}), 7.13-7.08(\mathrm{~m}, 2 \mathrm{H}), 6.88(\mathrm{~s}, 1 \mathrm{H}), 6.82-6.75(\mathrm{~m}$, $2 \mathrm{H}), 2.89(\mathrm{~s}, 3 \mathrm{H}) .{ }^{13} \mathrm{C}$ NMR $\left(150 \mathrm{MHz}, \mathrm{THF}-d_{8}\right) \delta 143.7,142.0,141.6$, 141.2, 138.4, 137.0, 136.6, 135.99, 135.97, 134.8, 134.7, 134.0, 133.8, 133.6, 132.0, 131.8, 130.4, 128.8, 127.3, 127.1, 126.75, 126.73, 125.9, $124.3,124.2,121.8,121.4,120.4,119.9,117.6,115.6,113.5,93.3,33.4$.

Compounds 14 and 15 (Deuterated 3 and 4). To the freshly prepared compounds 12 and $13,30-50 \mathrm{uL}$ of $\mathrm{D}_{2} \mathrm{O}$ was added via a microsyringe. The color of the reaction mixture turned back to yellow after the addition. ${ }^{1} \mathrm{H}$ NMR spectra were collected directly after addition. ${ }^{1} \mathrm{H}$ NMR $\left(600 \mathrm{MHz}\right.$, THF- $\left.d_{8}, 14\right) \delta 8.53(\mathrm{~d}, J=8.7 \mathrm{~Hz}, 2 \mathrm{H})$, $8.43(\mathrm{~d}, J=7.6 \mathrm{~Hz}, 2 \mathrm{H}), 8.09(\mathrm{~s}, 2 \mathrm{H}), 8.00(\mathrm{~d}, J=8.7 \mathrm{~Hz}, 2 \mathrm{H}), 7.68(\mathrm{~d}, J$ $=7.4 \mathrm{~Hz}, 2 \mathrm{H}), 7.47(\mathrm{td}, J=7.5,1.2 \mathrm{~Hz}, 2 \mathrm{H}), 7.32(\mathrm{t}, J=7.3 \mathrm{~Hz}, 2 \mathrm{H}), 4.32$ $(\mathrm{s}, 0.08 \mathrm{H}), 4.29(\mathrm{~s}, 0.57 \mathrm{H}) .{ }^{1} \mathrm{H}$ NMR $\left(400 \mathrm{MHz}, \mathrm{THF}-d_{8}, 15\right) 8.28(\mathrm{~d}, J$ $=7.7 \mathrm{~Hz}, 1 \mathrm{H}), 8.21(\mathrm{~d}, J=8.9 \mathrm{~Hz}, 1 \mathrm{H}), 7.92(\mathrm{~d}, J=9.0 \mathrm{~Hz}, 1 \mathrm{H}), 7.81-$ $7.67(\mathrm{~m}, 5 \mathrm{H}), 7.60(\mathrm{~d}, J=7.4 \mathrm{~Hz}, 1 \mathrm{H}), 7.42(\mathrm{t}, J=7.7 \mathrm{~Hz}, 1 \mathrm{H}), 7.27(\mathrm{t}, J$ $=7.4 \mathrm{~Hz}, 1 \mathrm{H}), 7.24-7.13(\mathrm{~m}, 2 \mathrm{H}), 2.78(\mathrm{~s}, 3 \mathrm{H})$.

General Computational Methods. Computed structure and property results were carried out using both GAMESS ${ }^{42}$ (structures and Hessians) and Gaussian09 ${ }^{43}$ (for NMR, UV and VCD) software packages. The B97- $\mathrm{D}^{44}$ density functional was used in combination with the Def2-TZVPP basis set ${ }^{45}$ for all geometry optimizations and Hessian (gas phase (GP)). The gradient convergence tolerance and the rootmean-square gradient were lowered to 0.00001 hartree/Bohr and to 0.000003 hartree/Bohr, respectively. In all calculations, a larger number of radial points in the Euler-MacLaurin quadrature and a finer Lebedev grid than the Army-grade grid were used ( $\mathrm{nrad}=155$ and nleb = 1202, respectively). The SCF density convergence criterion was lowered to 2.5 $\times 10^{-07}$, and the integral cutoff was lowered to $10^{-11}$. ${ }^{1} \mathrm{H}$ chemical shielding tensor data was determined using the CSGT method ${ }^{46,47}$ at the B97-D/Def2-TZVP(tetrahydrofuran)//B97-D/Def2-TZVPP level, and data referenced using a calibration method. ${ }^{48}$ Absorption energies were computed in tetrahydrofuran (THF) at the TD-CAMB3LYP ${ }^{21}$ / Def2-TZVP(THF)//B97-D/Def2-TZVPP(GP) level of theory. From the TD-DFT results, ECD spectra were simulated using a Gaussian band shape assumption. Reduction potential data was determined at the B97-3 ${ }^{27} /$ Def2-TZVPD(THF)//B97D/Def2-TZVPP(GP) level using $E^{\circ}=-\Delta E / n F$ where $n=1, F=1 \mathrm{eV}$, and referenced to $\mathrm{Ag} / \mathrm{AgCl}$. The B97-3 hybrid functional incorporates nonlocal exchange, which is important for this application. VCD and $\mathrm{p} K_{\mathrm{a}}$ calculations were performed at the B97-D/Def2-TZVPP and $\omega$ B97X-D ${ }^{49} /$ Def2-TZVPP level of theory, respectively. While the VCD for the neutral species were computed in $\mathrm{CHBr}_{3}$, the negatively charged structures were computed in THF. The simulated VCD spectrum consists of a sum of Lorentzian distributions centered on the computed VCD frequencies, with a fixed width and with the height proportional to the computed rotational constant. Effects of solvent in all cases employed the COSMO:ab initio continuum method $^{50,51}$ (see the Supporting Information for more detailed information regarding each of these properties).
*E-mail: kimb@tju.edu.cn

*E-mail: dean_spst@tju.edu.cn

We thank the National Basic Research Program of China (2015CB856500), the Qian Ren Scholar Program of China, and the Synergetic Innovation Center of Chemical Science and Engineering (Tianjin), for support of this work. Manuela Bruetsch is acknowledged for the initial efforts on this project and Yujia Wang is acknowledged for measurement of VCD spectra.

(1) Wu, Y.-T.; Siegel, J. S. Top. Curr. Chem. 2014, 349, 63.

(2) Seiders, T. J.; Baldridge, K. K.; Grube, G. H.; Siegel, J. S. J. Am. Chem. Soc. 2001, 123 (4), 517.

(3) Jackson, E. A.; Steinberg, B. D.; Bancu, M.; Wakamiya, A.; Scott, L. T. J. Am. Chem. Soc. 2007, 129 (3), 484.

(4) Steinberg, B. D.; Jackson, E. A.; Filatov, A. S.; Wakamiya, A.; Petrukhina, M. A.; Scott, L. T. J. Am. Chem. Soc. 2009, 131 (30), 10537.

(5) Wu, Y.-T.; Hayama, T.; Baldridge, K. K.; Linden, A.; Siegel, J. S. J. Am. Chem. Soc. 2006, 128, 6870-6884.

(6) Hsiao, C.-C.; Lin, Y.-K.; Liu, C.-J.; Wu, T.-C.; Wu, Y.-T. Adv. Synth. Catal. 2010, 352 (18), 3267.

(7) Allemann, O.; Baldridge, K. K.; Siegel, J. S. Org. Chem. Front. 2015, 2 (9), 1018.

(8) Allemann, O.; Duttwyler, S.; Romanato, P.; Baldridge, K. K.; Siegel, J. S. Science 2011, 332 (6029), 574.

(9) Miyaura, N.; Suzuki, A. Chem. Rev. 1995, 95 (7), 2457.

(10) Wu, Y.-T.; Bandera, D.; Maag, R.; Linden, A.; Baldridge, K. K.; Siegel, J. S. J. Am. Chem. Soc. 2008, 130 (32), 10729.

(11) For related compounds, see: Tian, X.; Roch, L. M.; Baldridge, K. K.; Siegel, J. S. Eur. J. Org. Chem. 2017, 2017 (19), 2801.

(12) Roch, L. M.; Zoppi, L.; Siegel, J. S.; Baldridge, K. K. J. Phys. Chem. C 2017, 121 (2), 1220.

(13) Zoppi, L.; Martin-Samos, L.; Baldridge, K. K. Acc. Chem. Res. 2014, 47 (11), 3310.

(14) Haddon, R. C.; Scott, L. T. Pure Appl. Chem. 1986, 58 (1), 137.

(15) Haddon, R. C. Acc. Chem. Res. 1988, 21 (6), 243.

(16) Haddon, R. C. J. Am. Chem. Soc. 1990, 112 (9), 3385.

(17) Haddon, R. C. Science (Washington, DC, U. S.) 1993, 261 (5128), 1545.

(18) Roch, L. M.; Baldridge, K. K. J. Chem. Theory Comput. 2017, 13 (6), 2650 .

(19) Seiders, T. J.; Baldridge, K. K.; Siegel, J. S.; Gleiter, R. Tetrahedron Lett. 2000, 41, 4519.

(20) Keal, T. W.; Tozer, D. J. J. Chem. Phys. 2005, 123 (12), 121103.

(21) Yanai, T.; Tew, D. P.; Handy, N. C. Chem. Phys. Lett. 2004, 393, 51.

(22) Laurent, A. D.; Jacquemin, D. Int. J. Quantum Chem. 2013, 113, 2019.

(23) Scott, L. T.; Hashemi, M. M.; Bratcher, M. S. J. Am. Chem. Soc. 1992, 114 (5), 1920. 
(24) Sygula, A.; Abdourazak, A. H.; Rabideau, P. W. J. Am. Chem. Soc. 1996, 118 (2), 339.

(25) Moskowitz, M.; Xu, H.; Wolf, C. Isr. J. Chem. 2016, 56 (11-12), 1052.

(26) Reist, M.; Testa, B.; Carrupt, P.-A.; Jung, M.; Schurig, V. Chirality 1995, 7 (6), 396.

(27) Joseph-Nathan, P.; Gordillo-Román, B. Vibrational Circular Dichroism Absolute Configuration Determination of Natural Products. Prog. Chem. Org. Nat. Prod. 2015, 100, 311.

(28) He, Y.; Wang, B.; Dukor, R. K.; Nafie, L. A. Appl. Spectrosc. 2011, $65(7), 699$.

(29) Nina, B.; Nakanishi, K.; Woody, R. W. Circular Dichroism: Principles and Applications, 2nd ed.; Wiley-VCH: New York, 2000.

(30) Petrukhina, M. A.; Andreini, K. W.; Peng, L.; Scott, L. T. Angew. Chem., Int. Ed. 2004, 43 (41), 5477.

(31) Higashibayashi, S.; Sakurai, H. J. Am. Chem. Soc. 2008, 130 (27), 8592.

(32) Tsuruoka, R.; Higashibayashi, S.; Ishikawa, T.; Toyota, S.; Sakurai, H. Chem. Lett. 2010, 39 (6), 646.

(33) Higashibayashi, S.; Tsuruoka, R.; Soujanya, Y.; Purushotham, U.; Sastry, G. N.; Seki, S.; Ishikawa, T.; Toyota, S.; Sakurai, H. Bull. Chem. Soc. Jpn. 2012, 85 (4), 450.

(34) Thilgen, C.; Diederich, F. Chem. Rev. 2006, 106 (12), 5049.

(35) Peng, X.; Komatsu, N.; Bhattacharya, S.; Shimawaki, T.; Aonuma, S.; Kimura, T.; Osuka, A. Nat. Nanotechnol. 2007, 2 (6), 361.

(36) Bordwell, F. G. Acc. Chem. Res. 1988, 21 (12), 456.

(37) Smith, A. P.; Lamba, J. J. S.; Fraser, C. L. Org. Synth. 2002, 78, 82.

(38) Majewski, M.; Nowak, P. Tetrahedron Lett. 1998, 39 (13), 1661.

(39) The second deprotonation, $\mathrm{p} K_{\mathrm{a} 2}$, displays similar behavior, with $\mathrm{p} K_{\mathrm{a} 2}$ 's similar to those of the corresponding structure, $\mathbf{3}$ or $\mathbf{5}$.

(40) Zimmerman, S. C. Top. Curr. Chem. 1993, 165, 71.

(41) Bauert, T.; Zoppi, L.; Koller, G.; Siegel, J. S.; Baldridge, K. K.; Ernst, K.-H. J. Am. Chem. Soc. 2013, 135 (34), 12857.

(42) Schmidt, M. W.; Baldridge, K. K.; Boatz, J. A.; Elbert, S. T.; Gordon, M. S.; Jensen, J. H.; Koseki, S.; Matsunaga, N.; Nguyen, K. A.; Su, S.; Windus, T. L.; Dupuis, M.; Montgomery, J. A. J. Comput. Chem. 1993, 14 (11), 1347.

(43) Frisch, M. J.; Trucks, G. W.; Schlegel, H. B.; Scuseria, G. E.; Robb, M. A.; Cheeseman, J. R.; Scalmani, G.; Barone, V.; Mennucci, B.; Petersson, G. A.; Nakatsuji, H.; Caricato, M.; Li, X.; Hratchian, H. P.; Izmaylov, A. F.; Bloino, J.; Zheng, G.; Sonnenberg, J. L.; Hada, M.; Ehara, M.; Toyota, K.; Fukuda, R.; Hasegawa, J.; Ishida, M.; Nakajima, T.; Honda, Y.; Kitao, O.; Nakai, H.; Vreven, T.; Montgomery, J. A., Jr.; Peralta, J. E.; Ogliaro, F.; Bearpark, M.; Heyd, J. J.; Brothers, E.; Kudin, K. N.; Staroverov, V. N.; Kobayashi, R.; Normand, J.; Raghavachari, K.; Rendell, A.; Burant, J. C.; Iyengar, S. S.; Tomasi, J.; Cossi, M.; Rega, N.; Millam, J. M.; Klene, M.; Knox, J. E.; Cross, J. B.; Bakken, V.; Adamo, C.; Jaramillo, J.; Gomperts, R.; Stratmann, R. E.; Yazyev, O.; Austin, A. J.; Cammi, R.; Pomelli, C.; Ochterski, J. W.; Martin, R. L.; Morokuma, K.; Zakrzewski, V. G.; Voth, G. A.; Salvador, P.; Dannenberg, J. J.; Dapprich, S.; Daniels, A. D.; Farkas, O.; Foresman, J. B.; Ortiz, J. V.; Cioslowski, J.; Fox, D. J. Gaussian 09, revision D.01; Gaussian, Inc.: Wallingford, CT, 2009.

(44) Grimme, S. J. Chem. Phys. 2006, 124 (3), 034108.

(45) Weigend, F.; Ahlrichs, R. Phys. Chem. Chem. Phys. 2005, 7 (18), 3297.

(46) Keith, T. A.; Bader, R. F. W. Chem. Phys. Lett. 1993, 210 (1-3), 223.

(47) Keith, T. A.; Bader, R. F. W. Chem. Phys. Lett. 1992, 194 (1-2), 1.

(48) Baldridge, K. K.; Siegel, J. S. J. Phys. Chem. A 1999, 103 (20), 4038.

(49) Chai, J.-D.; Head-Gordon, M. J. Chem. Phys. 2008, 128 (8), 084106.

(50) Klamt, A.; Schüürmann, G. J. Chem. Soc., Perkin Trans. 2 1993, 5, 799.

(51) Baldridge, K.; Klamt, A. J. Chem. Phys. 1997, 106 (16), 6622. 